\title{
Characteristics of Saliva in FK Ukrida Students After Chewing Paraffin, Xylitol and Sucrose Gum
}

\author{
Wan Aishah Fariha Binti Wan Nazri, William*, Flora Rumiati \\ Departemen Fisiologi Fakultas Kedokteran Universitas Kristen Krida Wacana, Jl. Tanjung Duren Raya No.4, \\ Jakarta Barat 11470, Indonesia \\ *Corresponding author : William@ukrida.ac.id
}

\section{ABSTRACT}

Data from the Ministry of Health of the Republic of Indonesia in 2009 shows that national sugar consumption per capita reaches $12 \mathrm{~kg} /$ year. Snacks consumed mostly were based on sucrose sugar and it turns out that sucrose is increasing the insidens of caries because sugar-based foods and drinks cause acid-resistant bacteria to obtain a suitable environment for growth. To overcome this problem sucrose was replaced with alcohol sugar such as xylitol, especially in chewing gum. However, it is still unknown the effect of xylitol on saliva. The purpose of this study was to see whether there were differences in salivary characteristics after consuming paraffin, xylitol chewing gum and sucrose chewing gum by looking at salivary $\mathrm{pH}$ values, reducing sugar levels in saliva and salivary flow rates. Saliva collection is done by spitting method then the total volume is divided by the time of collection to get the flow rate of saliva. Salivary $\mathrm{pH}$ is measured using a $\mathrm{pH}$ meter while reducing sugar levels are measured using the Benedict's test. The sample for this study consisted of 50 Ukrida FK students. The results of this study indicate that the highest salivary flow rate is after chewing xylitol chewing gum. While the reducing sugar levels in saliva are only found after chewing sucrose chewing gum. For salivary $\mathrm{pH}$ values, after chewing sucrose chewing gum the most acidic $\mathrm{pH}$ was obtained when compared to after chewing paraffin and xylitol chewing gum. From the research that has been done, after consuming paraffin, xylitol chewing gum and sucrose chewing gum, the highest salivary flow rate was obtained after consuming xylitol chewing gum, while the lowest was after consuming paraffin. Meanwhile, the highest $p H$ value of saliva was after consuming paraffin and the lowest was after consuming sucrose chewing gum. Meanwhile, reducing sugar levels in saliva was only found after consuming sucrose chewing gum and was not found after consuming paraffin and xylitol chewing gum. From this study it can be concluded that there are differences in the characteristics of saliva among FK Ukrida students after consuming paraffin, xylitol chewing gum and sucrose chewing gum.

Keywords : xylitol, sucrose, characteristic of saliva, salivary flow rate, salivary $\mathrm{pH}$ value level of reductive sugar in saliva.

\section{ABSTRAK}

Data dari Departemen Kesehatan Republik Indonesia 2009 menunjukkan konsumsi gula nasional per kapita mencapai $12 \mathrm{~kg} /$ tahun. Makanan ringan yang dikonsumsi oleh masyarakat banyak yang mengandung gula sukrosa dan kandungan tinggi sukrosa tersebut dapat meningkatkan insiden karies gigi, karena makanan dan minuman yang mengandung sukrosa menyebabkan bakteri tahan asam lebih mudah untuk bertumbuh. Untuk mengatasi masalah tersebut sukrosa, sukrosa dapat digantikan dengan gula alkohol seperti xylitol, terutama penggunaannya pada permen karet. Akan tetapi efek xylitol terhadap karakteristik saliva masih belum begitu diketahui. Tujuan penelitian ini 
adalah untuk melihat apakah ada perbedaan karakteristik saliva setelah mengkonsumsi paraffin, permen karet xylitol dan sukrosa dengan melihat nilai $\mathrm{pH}$ saliva, kadar gula pereduksi dalam saliva dan laju aliran saliva. Pengumpulan saliva dilakukan dengan spitting method, kemudian total volumenya dibagi dengan waktu pengumpulan untuk mendapatkan laju aliran saliva. Nilai $\mathrm{pH}$ saliva diukur menggunakan $\mathrm{pH}$ meter, sedangkan kadar gula pereduksi diukur menggunakan Benedict's test. Sampel bagi penelitian ini terdiri dari 50 mahasiswa FK Ukrida. Dari penelitian yang telah dilakukan, didapatkan hasil laju aliran saliva tertinggi adalah setelah mengkonsumsi permen karet xylitol sedangkan yang terendah adalah setelah mengkonsumsi paraffin. Sedangkan nilai $\mathrm{pH}$ saliva paling tinggi adalah setelah mengkonsumsi paraffin dan terendah setelah mengkonsumsi permen karet sukrosa. Sementara itu, kadar gula pereduksi dalam saliva hanya ditemukan setelah mengkonsumsi permen karet sukrosa dan tidak ditemui setelah mengkonsumsi paraffin dan permen karet xylitol. Dari penelitian ini dapat disimpulkan bahwa terdapat perbedaan karakteristik saliva pada mahasiswa FK Ukrida setelah mengkonsumsi paraffin, permen karet xylitol dan sukrosa.

Kata kunci : xylitol, sukrosa, karakteristik saliva, laju aliran saliva, nilai $\mathrm{pH}$ saliva, kadar gula pereduksi dalam saliva

\section{PENDAHULUAN}

Kesehatan gigi dan mulut adalah suatu unsur yang penting yang tidak dapat dipisahkan dari kesehatan tubuh. Hal ini karena, faktor-faktor penyebab dan risiko penyakit gigi dan mulut sering sama dengan yang terlibat dalam penyakit lainnya di luar gigi dan mulut. ${ }^{1}$ Kesehatan gigi dan mulut memiliki hubungan yang sangat erat dengan perilaku kebersihan diri seseorang. Perilaku pemeliharaan yang baik akan sangat berperan dalam menentukan derajat kesehatan individu. ${ }^{2,3}$ Yang menjadi masalah adalah keluhan mengenai gigi dan mulut masih sangat tinggi dan menempati urutan ke enam keluhan kesehatan masyarakat di Indonesia. ${ }^{4}$

Dari Data global didapatkan penyakit gigi dan mulut juga menjadi masalah di dunia dan tidak hanya di Indonesia saja. Oral Health Media mengeluarkan data pada April 2012, yaitu sebanyak $60-90 \%$ anak usia sekolah dan hampir semua orang dewasa di seluruh dunia memiliki masalah gigi. ${ }^{5}$ Di Asia dan Amerika Latin, karies gigi merupakan suatu penyakit yang sangat umum. National Institution of Health di Amerika Serikat juga pernah melaporkan karies gigi merupakan penyakit kronis yang sangat umum diderita anak, setidaknya 5 kali lebih sering terjadi dibandingkan asma. ${ }^{4,5}$ Di Indonesia juga sama yaitu karies gigi dan penyakit periodontal adalah masalah gigi dan mulut yang paling sering dijumpai. ${ }^{6}$
Dari Departemen Kesehatan Republik Indonesia dalam Riset Kesehatan Dasar 2018 didapatkan data, yaitu 90,2\% anak di bawah usia 5 tahun mengalami karies gigi dan setidaknya $88,8 \%$ orang dewasa juga mengalami hal yang sama. Dari semua yang mengalami masalah gigi dan mulut, sekitar $95,5 \%$ yang tidak mengunjungi fasilitas kesehatan untuk masalah gigi dan mulut yang dideritanya. ${ }^{7}$

Karies gigi adalah suatu kerusakan jaringan keras gigi yang terdiri dari email gigi, dentum dan sementum yang disebabkan oleh aktivitas asam dari bakteri sebagai hasil dari fermentasi atau peragian karbohidrat. ${ }^{8,9}$ Mikroorganisme utama penyebab karies adalah Streptococcus mutans, mikroorganisme ini dapat berkolonisasi di permukaan gigi dan menghasilkan asam dengan cepat sehingga menyebabkan proses demineralisasi pada gigi. ${ }^{9}$

Proses demineralisasi dapat akibat aktivitas bakteri dapat menimbulkan rasa nyeri sehingga mampu mengurangi kualitas hidup individu. ${ }^{5}$ Faktor-faktor yang berhubungan dengan terbentuknya karies gigi, yaitu jenis kelamin, usia, status sosial ekonomi, pola diet dan kebiasaan menjaga kebersihan gigi dan mulut. ${ }^{4}$ Karies gigi selain mempengaruhi gigi, juga dapat menyebabkan penyakit sistemik seperti seperti jantung, stroke, infeksi pernapasan, osteoporosis dan gangguan gastrointestinal. ${ }^{10}$ 
Di Indonesia, makanan yang mengandung gula adalah menu utama dari dari diet masyarakat sehari-hari. Data dari Departemen Kesehatan Republik Indonesia 2009 menunjukkan konsumsi gula nasional per kapita mencapai $12 \mathrm{~kg} / \mathrm{tahun}$. Gula sukrosa tidak hanya terdapat pada makanan pokok, tetapi juga pada pelbagai makanan ringan yang ada di Indonesia. Pemilihan gula sukrosa sebagai sumber gula adalah karena biaya produksi yang cukup murah, dan bahan bakunya mudah diperoleh. Akan tetapi hal ini harus menimbulkan peringatan bagi kita, karena gula sukrosa dapat menyebabkan penyakit gigi, dan mulut, serta penyakit sistemik lainnya akibat dari karies gigi. ${ }^{711}$

Sekarang ini untuk mengatasi permasalahan akibat penggunaan sukrosa pada makanan ringan, dalam hal ini permen karet, didapatkan suatu solusi yaitu menggantikannya dengan gula alkohol, karena gula alkohol bersifat nonkariogenik. Jenis-jenis gula alkohol, antara lain adalah sorbitol, xylitol dan mannitol, dengan xylitol lebih banyak digunakan sebagai penganti sukrosa. Xylitol tidak dapat dimetabolisme oleh Streptococcus mutans, sehingga tidak terbentuk suasana asam dan tidak terjadi demineralisasi serta tidak terjadi pembentukan karies. Dari sisi fisik permen karetnya, permen karet dapat menghilangkan debris makanan dan plak gigi. Karena efektifitas permen karet xylitol maka penggunaannya diharapkan dapat menurunkan insiden karies gigi. ${ }^{7,11}$

Dari semua efek baik yang dimiliki xylitol, masih kurang diketahui efeknya pada saliva. Oleh karena itu, peneliti tertarik melakukan penelitian untuk melihat apakah ada perbedaan karakteristik saliva setelah mengkonsumsi parafin, permen karet xylitol dan sukrosa, dengan melihat nilai $\mathrm{pH}$ saliva, kadar gula pereduksi dalam saliva dan laju aliran saliva.

\section{METODOLOGI PENELITIAN}

Desain penelitian ini adalah penelitian deskriptif dengan jumlah subyek penelitian sebanyak 50 orang yang memenuhi kriteria inklusi dan eksklusi. Penelitian ini dilakukan di kampus FK UKRIDA mulai Agustus hingga Desember 2019. Sampel diambil menggunakan metode simple random sampling. Kriteria inklusi yang dipakai adalah semua mahasiswa/i FK Ukrida angkatan 2016. Sedangkan kriteria eksklusinya adalah mahasiswa yang sakit psikis atau fisik, mahasiswa yang menghadapi ujian pada hari pengambilan sampel, mahasiswa yang menggunakan obat antikolinergik, mahasiswa yang menderita penyakit sistemik dan mahasiswa yang mengalami dehidrasi.

Alat dan bahan yang digunakan adalah gelas ukur, $\mathrm{pH}$ meter, tabung reaksi, penangas air, rak tabung, blok parafin, permen karet xylitol, permen karet sukrosa dan Benedict's solution.

Saliva dan laju aliran saliva dikumpulkan dengan metode spitting yaitu subjek penelitian berhenti makan, minum, menyikat gigi satu jam sebelum dilakukan pengumpulan saliva. Saliva dikumpulkan di dalam mulut dengan posisi bibir tertutup, kemudian dikeluarkan ke dalam gelas ukur setiap satu menit. ${ }^{12}$

Pengukuran laju aliran saliva dilakukan dengan cara subjek penelitian mengunyah parafin selama 5 menit sebelum pengambilan saliva, setelah itu saliva yang terkumpul di mulut dikeluarkan ke dalam gelas ukur. Volume saliva yang terkumpul diukur dan dibagi dengan waktu 5 menit untuk mendapatkan laju aliran saliva (ml/menit). Prosedur yang sama dilakukan untuk xylitol dan sukrosa. Pengambilan data dilakukan pada hari yang berbeda untuk masing-masing parafin, xylitol dan sukrosa, tetapi waktu pengambilan data sama, yaitu pada jam 10 pagi sampai jam 12.00 WIB siang.

Pengukuran $\mathrm{pH}$ saliva dilakukan dengan cara elektroda $\mathrm{pH}$ meter dimasukan ke dalam saliva yang telah terkumpul, kemudian ditunggu sampai angka pada $\mathrm{pH}$ meter berhenti di angka dua digit. ${ }^{12}$

Terakhir, untuk pengukuran kadar gula pereduksi dalam saliva, teteskan 1cc saliva yang telah dikumpulkan ke dalam tabung reaksi. Tambahkan 3 tetes Benedict's solution ke dalam tabung reaksi. Panaskan selama 3 menit hingga 4 menit di dalam penangas air yang mendidih. Perhatikan perubahan warna. Catat hasil perubahan warna. Ulangi langkah ini pada semua saliva yang telah dikumpulkan. ${ }^{13}$ Apabila tidak terdapat perubahan warna atau warna biru, berarti kadar gula pereduksi adalah $<0,5 \%$. Apabila berubah menjadi warna hijau, berarti 
kadar gula pereduksi adalah $0,5 \%-1 \%$. Warna yang berubah menjadi kuning berarti kadar gula pereduksi adalah $1 \%-1,5 \%$ dan apabila warna berubah menjadi warna jingga atau lumpur keruh, kadar gula pereduksi adalah $2 \%-3,5 \%$. $^{13}$

\section{Keterangan Lolos Kaji Etik}

Penelitian ini telah lolos kaji etik dari Komisi Etik Penelitian FK Ukrida, No 897/SLKE-IM/UKKW/FKIK/KE/V/2019.

\section{HASIL ANALISIS DATA}

1. Karakteristik Umum Responden Tabel 1. Karakteristik Umum Responden

\begin{tabular}{|c|c|c|}
\hline & $\mathrm{n}=\mathbf{5 0}$ & $\begin{array}{c}\text { Persentase } \\
(\%)\end{array}$ \\
\hline \multicolumn{3}{|c|}{ Jenis Kelamin } \\
\hline Laki-laki & 20 & 40 \\
\hline Perempuan & 30 & 60 \\
\hline \multicolumn{3}{|l|}{ Usia } \\
\hline 19 & 1 & 2 \\
\hline 20 & 7 & 14 \\
\hline 21 & 24 & 48 \\
\hline 22 & 16 & 32 \\
\hline 23 & 1 & 2 \\
\hline 24 & 1 & 2 \\
\hline \multicolumn{3}{|c|}{ Tinggi Badan (m) } \\
\hline $1.50-1.54$ & 8 & 16 \\
\hline $1.55-1.59$ & 12 & 24 \\
\hline $1.60-1.64$ & 10 & 20 \\
\hline $1.65-1.69$ & 5 & 10 \\
\hline $1.70-1.74$ & 14 & 28 \\
\hline $1.75-1.79$ & 1 & 2 \\
\hline \multicolumn{3}{|c|}{ Berat Badan (kg) } \\
\hline $43-51$ & 15 & 30 \\
\hline $52-60$ & 16 & 32 \\
\hline $61-69$ & 7 & 14 \\
\hline $70-78$ & 7 & 14 \\
\hline $79-87$ & 2 & 4 \\
\hline $88-96$ & 2 & 4 \\
\hline $97-105$ & 1 & 2 \\
\hline \multicolumn{3}{|c|}{ Indeks Massa } \\
\hline \multicolumn{3}{|c|}{ Tubuh (IMT) } \\
\hline$\leq 18,4$ & 7 & 14 \\
\hline $18,5-22,9$ & 21 & 42 \\
\hline $23,0-24,9$ & 10 & 20 \\
\hline $25,0-29,9$ & 7 & 14 \\
\hline$\geq 30,0$ & 5 & 10 \\
\hline
\end{tabular}

Berdasarkan tabel 1, dari 50 subyek ini 20 merupakan laki-laki dan 30 adalah perempuan. Didapatkan sebagian besar subyek berusia 21 tahun (48\%). Sebesar 28\% subyek penelitian memiliki ketinggian antara 1,7 m hingga 1,74 m. Sedangkan hanya $2 \%$ yang memiliki ketinggian di antara $1,75 \mathrm{~m}$ hingga $1,79 \mathrm{~m}$. Untuk berat badan, $36 \%$ subyek penelitian memiliki berat badan dari $52 \mathrm{~kg}-60 \mathrm{~kg}$ dan $2 \%$ memiliki berat badan diantara $97 \mathrm{~kg}-105 \mathrm{~kg}$. Sebagian besar atau $42 \%$ subyek penelitian memiliki IMT normal yaitu 18,5-22,9 dan $10 \%$ memiliki IMT $\geq 30,0$.

\section{Rerata dan Standar Deviasi Laju Aliran Saliva}

Tabel 2. Rerata dan Standar Deviasi Laju Aliran Saliva

\begin{tabular}{ccc}
\hline Kelompok & n & $\begin{array}{c}\text { Rerata } \pm \text { Standar } \\
\text { Deviasi Laju Aliran } \\
\text { Saliva (ml/menit) }\end{array}$ \\
\hline $\begin{array}{c}\text { Parafin } \\
\text { Permen }\end{array}$ & 50 & $0,5280 \pm 0,2792$ \\
Karet Xylitol \\
Permen \\
Karet & 50 & $0,6360 \pm 0,3652$ \\
Sukrosa & 50 & $0,5680 \pm 0,2751$ \\
\hline
\end{tabular}

Tabel 2 menunjukkan bahwa rerata tertinggi laju aliran saliva adalah pada permen karet xylitol dengan rerata $0,6360 \pm 0,3652$ $\mathrm{ml} / \mathrm{menit}$ sedangkan yang terendah adalah paraffin dengan rerata $0,5280 \pm 0,2792$.

\section{Rerata dan Standar pH Saliva}

Tabel 3. Rerata dan Standar Deviasi pH Saliva

\begin{tabular}{ccc}
\hline Kelompok & n & $\begin{array}{c}\text { Rerata } \pm \text { Standar } \\
\text { Deviasi pH Saliva }\end{array}$ \\
\hline Parafin & 50 & $8,0176 \pm 0,5618$ \\
$\begin{array}{c}\text { Permen } \\
\text { Karet Xylitol } \\
\text { Permen } \\
\text { Karet }\end{array}$ & 50 & $7,5484 \pm 0,7214$ \\
Sukrosa & 50 & $4,8754 \pm 0,8634$ \\
\hline
\end{tabular}

Dari tabel 3, pH saliva pada parafin memiliki nilai rerata $\mathrm{pH}$ tertinggi yaitu $8,0176 \pm 0,5618$ 
dan rerata $\mathrm{pH}$ yang terendah pada permen karet sukrosa yaitu 4,8754 $\pm 0,8634$.

\section{Rerata dan Standar Kadar Gula Pereduksi dalam Saliva}

Tabel 4. Rerata dan Standar Deviasi Kadar Gula Pereduksi dalam Saliva

\begin{tabular}{ccc}
\hline Kelompok & n & $\begin{array}{c}\text { Rerata } \pm \text { Standar } \\
\text { Deviasi Kadar Gula } \\
\text { Pereduksi dalam Saliva } \\
(\%)\end{array}$ \\
\hline Parafin & 50 & $0,25 \pm 0,00$ \\
$\begin{array}{c}\text { Permen } \\
\text { Karet Xylitol } \\
\text { Permen } \\
\text { Karet }\end{array}$ & 50 & $0,25 \pm 0,00$ \\
Sukrosa & 50 & $1,64 \pm 1,074$ \\
\hline
\end{tabular}

Pada tabel 4 didapatkan kadar gula pereduksi dalam saliva, parafin dan permen karet xylitol memiliki rerata $0,25 \%$ dan permen karet sukrosa memiliki rerata tertinggi dengan rerata 1,64 \pm 1,074 .

\section{PEMBAHASAN}

Dalam penelitian ini didapatkan laju aliran saliva setelah mengkonsumsi parafin lebih rendah jika dibanding dengan setelah mengunyah permen karet xylitol. Hal ini sesuai dengan penelitian (Andayani R, dkk, 2016). ${ }^{14}$ Selain itu, dalam penelitian yang dilakukan oleh (Soderling, dkk, 2015) juga menunjukkan bahwa laju aliran saliva untuk permen karet xylitol dan sukrosa lebih tinggi jika dibandingkan dengan parafin. $^{15}$ Aliran saliva yang lebih tinggi disebabkan rangsangan yang lebih banyak pada permen xylitol dibandingkan dengan parafin, yaitu rangsangan kimiawi dan mekanis. ${ }^{16}$ Stimulus mekanis seperti pengunyahan permen karet dapat merangsang peningkatan sekresi saliva dengan kelenjar air liur yang terstimulasi oleh stimulus mekanis ini adalah kelenjar saliva parotis. ${ }^{17}$ Sedangkan pada pengaruh stimulus kimiawi, substansi kimia yang terdapat pada permen karet, menyebabkan rangsangan pada reseptor pengecap, dalam hal ini rasa manis yang kemudian akan merangsang peningkatan sekresi dari saliva. ${ }^{16}$ Akan tetapi terdapat perbedaan antara mengunyah permen karet xylitol dengan sukrosa, yaitu permen karet xylitol laju aliran salivanya lebih tinggi daripada sukrosa. Walaupun sama-sama menstimulasi mekanik dan kimiawi, xylitol memiliki rasa manis dan pedas dibandingkan dengan sukrosa yang hanya memiliki rasa manis. Rasa pedas tersebut sangat kuat menstimulasi keluarnya saliva, sehingga laju aliran saliva pada xylitol didapatkan lebih tinggi dibandingkan sukrosa. ${ }^{17}$

Hasil untuk $\mathrm{pH}$ saliva bagi penelitian ini tidak jauh berbeda dengan penelitian oleh (Rodian, dkk, 2011) yang menunjukkan hasil pH pada kelompok yang diberikan permen karet sukrosa, memiliki $\mathrm{pH}$ air liur yang lebih rendah dibandingkan dengan permen karet xylitol. Hal ini dapat terjadi karena, sukrosa disintesis lebih cepat dari karbohidrat lain menjadi glukan dan fruktan. Glukan ini kemudian menghasilkan energi dan asam laktat melalui glikolisis bakteri sehingga menyebabkan $\mathrm{pH}$ air liur turun. ${ }^{17}$ Sedangkan pada xylitol $\mathrm{pH}$ saliva lebih karena xylitol tidak dapat difermentasi oleh Streptococcus mutans dan mikroorganisme lain, sehingga tidak menghasilkan asam dan menurunkan $\mathrm{pH}$ saliva. ${ }^{18}$ Metabolisme xylitol pada bakteri Streptococcus mutans sebagai berikut, ketika xylitol masuk ke dalam sel bakteri, xylitol diubah menjadi xylitol-5-fosfat, xylitol-5-fosfat tidak dapat dimetabolisme oleh bakteri sehingga terjadi penurunan energi dan asam laktat yang dihasilkan oleh proses glikolisis Streptococcus mutans kurang terbentuk, sehingga $\mathrm{pH}$ saliva tidak terlalu turun. ${ }^{17}$ Nilai $\mathrm{pH}$ parafin adalah paling tinggi dibanding dengan permen karet sukrosa dan xylitol. Hal tersebut terjadi karena jumlah Streptococcus mutans menurun setelah mengkomsumsi paraffin, sehingga pembentukan asam laktat berkurang dan $\mathrm{pH}$ cenderung tidak turun. ${ }^{19}$

Pada hasil gula pereduksi didapatkan hasil yang lebih tinggi pada sukrosa dibandingkan parafin dan xylitol. Sukrosa memiliki gugus aldehid dan gugus keto bebas pada ujung rantai sehingga dapat menerima elektron atau melepaskan oksigen (gula pereduksi). ${ }^{20}$ Parafin 
adalah alkana yang memiliki gugus hidrokarbon jenuh dan tidak dapat mereduksi, sama seperti xylitol yang tidak memiliki gugus keton atau aldehid bebas, sehingga tidak dapat mereduksi. ${ }^{20}$ Ini menunjukkan bahwa parafin dan permen karet xylitol tidak terdapat gula pereduksi sedangkan dalam permen karet sukrosa, terdapat gula pereduksi. Pada penelitian (Nakagawa, dkk, 2007) juga didapatkan hasil yang sama yaitu didapatkan gula pereduksi sebesar 16,50 $\pm 5,38$ yang akan semakin menurun seiring dengan banyaknya menelan. ${ }^{21}$

\section{KESIMPULAN}

Dari penelitian yang telah dilakukan, setelah mengkonsumsi parafin, permen karet xylitol dan permen karet sukrosa didapatkan laju aliran saliva tertinggi adalah setelah mengkonsumsi permen karet xylitol sedangkan yang terendah adalah setelah mengkonsumsi parafin. Sedangkan nilai $\mathrm{pH}$ saliva paling tinggi adalah setelah mengkonsumsi parafin dan terendah setelah mengkonsumsi permen karet. Sementara itu, kadar gula pereduksi dalam saliva hanya ditemukan setelah mengkonsumsi permen karet sukrosa dan tidak ditemui setelah mengkonsumsi parafin dan permen karet xylitol. Dari penelitian ini dapat disimpulkan bahwa terdapat perbedaan karakteristik saliva pada mahasiswa FK Ukrida setelah mengkonsumsi parafin, permen karet xylitol dan sukrosa.

\section{SARAN}

1. Permen karet xylitol lebih disarankan dikonsumsi untuk memastikan kesehatan mulut tetap terjaga dan dapat mencegah terjadinya karies.

2. Dihimbau juga kepada mahasiswa untuk mengatur konsumsi gula secukupnya supaya tidak berlebih.

3. Mahasiswa juga dihimbau untuk tetap menyikat gigi secara teratur berkumur atau ditambah dengan mouthwash, dan penggunaan dental floss untuk mencegah karies.
4. Untuk peneliti selanjutnya disarankan untuk penelitian lanjutan mengenai aktivitas enzim saliva dalam rongga mulut pasca mengunyah permen karet.

\section{DAFTAR PUSTAKA}

[1] Ramadhan A, Cholil, Sukmana B. Hubungan tingkat pengetahuan kesehatan gigi dan mulut terhadap angka karies gigi di SMPN 1 Marabahan. Dentino Jurnal Kedokteran Gigi. 2016;1(2):173-6.

[2] Sutjipto C, Wowor VNS, Kaunang WPJ. Gambaran tindakan pemeliharaan kesehatan gigi dan mulut anak usia 10-12 tahun di SD Kristen Eben Haezar 02 Manado. Jurnal eBiomedik. 2013; 1(1):697-706.

[3] Gede YI, Pandelaki K, Marianti NW. Hubungan pengetahuan kebersihan gigi dan mulut dengan status kebersihan gigi dan mulut pada siswa SMA Negeri 9 Manado. Jurnal e-GiGi. 2013; 1(2):84-8.

[4] Susi S, Bachtiar H, Azmi U. Hubungan status sosial ekonomi orang tua dengan karies pada gigi sulung anak umur 4 dan 5 tahun. Majalah Kedokteran Andalas. 2012;36(1):96-105.

[5] Silaban S. Prevalensi karies gigi geraham pertama permanen pada anak umur $8-10$ tahun di SD kelurahan Kawangkoan Bawah. Jurnal Ilmiah Kedokteran Gigi. 2013;1(2):1-8.

[6] Budisuari, A. and Mikrajab, M. Hubungan pola makan dan kebiasaan menyikat gigi dengan kesehatan gigi dan mulut (karies) di Indonesia. Buletin Penelitian Sistem Kesehatan. 2010;13(1):83-91.

[7] Kementerian Kesehatan RI. Laporan hasil riset kesehatan dasar 2018, Jakarta: Kementerian Kesehatan RI; 2018.

[8] Santik YDP. Pentingnya kesehatan gigi dan mulut dalam menunjang produktivitas atlet. Media Ilmu Kelolahragawaan Indonesia. 2015;5(2):13-17.

[9] Mamengko W, Kawengian SES, Siagian KV. Gambaran komsumsi jajanan dan status karies pada anak usia 3-5 tahun di Kelurahan Rinegetan Kecamatan Tondano Barat. Jurnal e-GiGi. 2016; 4(1):17-22. 
[10] Larasati R. Hubungan kebersihan mulut dengan penyakit sistemik dan usia harapan hidup. Jurnal Skala Husada. 2012;9(1):97104.

[11] Savita A, Sungkar S, Chismirina S. Perbandingan laju aliran saliva sebelum dan sesudah mengunyah permen karet nonxylitol dan xylitol pada anak usia 10-12 tahun (studi pada murid sekolah dasar negeri 57 Banda Aceh). Journal Caninus Dentistry. 2017;2(2)

[12] Pradanta YE, Adhani R, Khatimah IH. Hubungan kadar ph dan volume saliva terhadap indeks karies masyarakat Menginang Kecamatan Lokpaikat Kabupaten Tapin. Dentino Jurnal Kedokteran Gigi. 2016; 1(2):h.158-63

[13] Gandasoebrata R. Penuntun laboratorium klinik. Jakarta. Penerbit Dian Rakyat. 2013

[14] Andayani R, Sunnati, Sholiha A. Perbedaan laju aliran saliva terstimulasi antara pengunyahan parafin dengan permen karet xylitol pada pasien terindikasi gerd. ODONTO Dental Journal 2016; 3 (2):h.105-10

[15] Sonderling E, Rekola M, Makinen KK, Scheinin A. Turku sugar studies XXI: xylitol, sorbitol, fructose, and sucrose induced physico chemical change in saliva. Acta Odontologica Scandinavica 2015;34:397-403

[16] Indriana T. Perbedaan laju aliran saliva dan $\mathrm{pH}$ karena pengaruh stimulus kimiawi dan mekanis. Jurnal Meditek Kedokteran. 2011; 17(44):h.1-5

[17] Rodian M, Satari MH, Rolleta E. Efek mengunyah permen karet yang mengandung sukrosa, xylitol, probiotik terhadap karakteristik saliva. Dentika Dental Jurnal 2011; 16 (1):h.44-8

[18] Hidayati NA, Kaidah S, Sukmana BI. Efek pengunyahan permen karet yang mengandung xylitol terhadap peningkatan pH saliva. Dentino Jurnal Kedokteran Gigi 2014; 2 (1)

[19] Llop RM, Jimeno FG, Acien RM, Dalmau B. Effect of xylitol chewing gum on salivary flow rate, $\mathrm{pH}$, buffering capacity and presence of Streptococcus mutans in saliva. European Journal of Paediatric Dentistry. 2010; 11(1):h.9-14

[20] Sumardjo, Damin. Pengantar kimia: buku panduan mahasiswa kedokteran dan program strata 1 fakultas bioeksata. Buku Kedokteran EGC. 2009.

[21] Nakagawa K, Watanabe S, Pai C, Minami M, Suzuki A, Takamori K. The concentration of gum component in saliva before and after swallowing during prolonged gum chewing. Pediatric Dental Journal;17(1):79-83. 